Abstracta Iranica

Revue bibliographique pour le domaine irano-aryen

Volume 34-35-36 | 2017

Comptes rendus des publications de 2011-2013

\title{
David Durand-Guédy. Location of Rule in a Context of Turko-Mongol Domination
}

\author{
Jürgen Paul
}

\section{OpenEdition}

1 Journals

\section{Electronic version}

URL: http://journals.openedition.org/abstractairanica/41822

DOI: 10.4000/abstractairanica.41822

ISSN: 1961-960X

Publisher:

CNRS (UMR 7528 Mondes iraniens et indiens), Éditions de l'IFRI

\section{Electronic reference}

Jürgen Paul, « David Durand-Guédy. Location of Rule in a Context of Turko-Mongol Domination », Abstracta Iranica [Online], Volume 34-35-36 | 2017, document 8, Online since 30 December 2016, connection on 26 September 2020. URL : http://journals.openedition.org/abstractairanica/41822 ; DOI : https://doi.org/10.4000/abstractairanica.41822

This text was automatically generated on 26 September 2020.

Tous droits réservés 


\title{
David Durand-Guédy. Location of Rule in a Context of Turko-Mongol Domination
}

\author{
Jürgen Paul
}

\section{REFERENCES}

David Durand-Guédy. « Location of Rule in a Context of Turko-Mongol Domination », in : D. Durand-Guédy, ed., Turko-Mongol Rulers, Cities and City Life. Leiden-Boston, Brill, 2013, p. 1-20.

1 The edited volume goes back to a conference held at Tokyo University, September 12-13, 2009; the conference also was part of Durand-Guédy's research project "Ruling from the Outside" (see above, R4-1N4-6). The introduction, "Location of Rule", furnishes some more theoretical background thoughts and puts Durand-Guédy's research project into a larger context. Durand-Guédy identifies Jean Aubin as one of the crucial figures, he quotes Aubin at some length for the general history of the situation of cities in the new context of Turko-Mongol rule. The new "pastoral city" ("association ville-pâturage" in Aubin's terms) can be shown to have existed in a number of countries, but in general, urbanism declined. Durand-Guédy also gives some references to new research on the dwellings of sultans, palaces and tents (his own contribution to the volume is called "The tents of the Seljuqs", 149-189). In the second part of the introduction, he gives summaries of the eleven chapters of the book which I will not condense further here. In the third part, concluding remarks, Durand-Guédy discusses lines for further research. He points to the potential of bringing archeology in, and as an example, he (quite rightly) adduces the results of the French-Uzbek archeological mission in Samarqand (which are a basis for Yury Karev's brilliant contribution to the volume: "From Tents to City. The Royal Court of the Western Qarakhanids between Bukhara and Samarqand", 99-147). A second desideratum which he notes are terminological studies where he calls our attention to the various terms 
(in Arabic, Persian, and Chinese) for a "capital" city or a royal encampment. The third element in the concluding remark is about a thing which he claims the volume has accomplished: to "dispel a spectre that has been haunting scholarship on the TurkoMongol rulers: the spectre of nomadism" (13). This certainly is true if one takes into account that dispelling a spectre does not mean that we will never see it again.

\section{AUTHORS}

JÜRGEN PAUL

Université de Halle 